\title{
Perception of Departmental Heads and Chief Executives towards Hospital HR Management Issues: A Comparison of Public and Private Hospitals in India
}

\author{
Gaurav Singh \\ Research Scholar, Uttar Pradesh Rajershree Tandon University \\ Allahabad, UP, 211001, India \\ E-mail: gaurgaurav18@rediffmail.com
}

\begin{abstract}
Ajay Singh (Corresponding author)
Department of Business Studies, Meerut Institute of Engineering \& Technology

NH-58, Baghpat Bypass, Meerut, 250005, India

E-mail: ajayks10@gmail.com
\end{abstract}

\begin{abstract}
Shashi Singh
Department of Education, Meerut Institute of Engineering \& Technology

NH-58, Baghpat Bypass, Meerut, 250005, India

E-mail: shashisingh1509@gmail.com
\end{abstract}

Accepted: July 05, 2012 Published: August 09, 2012

Doi:10.5296/ijhrs.v2i3.2217ＵRL: http://dx.doi.org/10.5296/ijhrs.v2i3.2217

\begin{abstract}
This paper analyses the perception of public and private hospital departmental heads and chief executives towards hospital management issues and compare their perceptions. A survey was conducted on private and public staff members. A total of 200 members formed the sample of which 100 belonged to public hospitals and 100 to private hospitals. The data were analysed with the help of $t$ test analysis and the explanation of the responses of the respondents. The study reveals that there is no significant difference in the perceptions of heads towards the hospital management issues. It is also revealed that though there is no significant difference, yet private hospitals scores over public hospitals.
\end{abstract}


Keywords: Public hospital, Private hospital, Departmental heads, Hospital Management

\section{Introduction}

PricewaterhouseCoopers in its emergence market report 2007 on 'Healthcare in India' states following:

"Healthcare is one of India's largest sectors, in terms of revenue and employment, and the sector is expanding rapidly. During the 1990s, Indian healthcare grew at a compound annual rate of $16 \%$. Today the total value of the sector is more than $\$ 34$ billion. This translates to $\$ 34$ per capita, or roughly $6 \%$ of GDP. By 2012 , India's healthcare sector is projected to grow to nearly $\$ 40$ billion. The private sector accounts for more than $80 \%$ of total healthcare spending in India."

However, the Indian healthcare system is plagued with numerous problems. Public hospitals are criticized for poor management, unhygienic conditions, unavailability of doctors, shortage of infrastructure and resources to meet the swelling number of patients and apathetic attitude of administrative staff etc. On the other hand private hospitals are criticized for their basic intention of treating itself as a corporate entity, where money becomes more important than humanity. In fact because of the difference in stated goals, it is evident that the private sector attracts and treats persons who can pay and are non-emergency situations hence there is already a selecting out of patients. The public sector, on the other hand, seeks to provide universal access and therefore the patient load is always higher than the intended capacity. These different goals get reflected in the case mix, social background of patients and rate of patient turnover in the private and public hospitals (Baru, Qadeer \& Priya, 2000)

That is why, hospital administration and management has become one of the major areas of research and study, particularly in developing countries. Hospitals are multifaceted entities which generally require most of the concepts of management studies to survive and perform effectively. Scott (1966) defined hospitals as complex organizations, with goals, tasks, control systems, and relationships of authority that are articulated in both formal and informal ways. Thus, hospitals are complex structure of man, machine and management, where quality of end results depends upon many factors. Involvement of the human factor is greater in hospital and hospital management. Such human interface makes the task of hospital that much difficult as characteristics of incoming patients varies widely on their emotion, economic and culture quotient. Not a single element of hospital management system can be compromised if a hospital wants to achieve its stated objectives from the patients' point of view. The informal communication system is as much important as the formal system in hospital management. Good machines to diagnose and test various diseases, qualified doctors to make truthful recommendations, humane support staff to help fulfill basic requirements of the patients and effective system for the smooth delivery of services to the patients, each function is important in hospital management.

Organizing involves analysis of activities to be performed for the accomplishment of organizational objectives, grouping them into various departments and section so that these can be assigned to various individuals and delegating them appropriate authority. Hospitals 
are characterized by a dual pyramid of an organization because of traditional relationship of the medical staff to administrative staff. Organization structures are a basic framework within which the manager's decision making behavior takes place. Structure basically deals with relationships. Structure is the pattern in which various parts or components are interrelated or interconnected. Organizational chart is a diagrammatic form which shows the major functions and their respective relationships, the channels of formal authority and the relative authority of each respective function. The chart shows the formal relationships.

There are many differences among underdeveloped, developing and developed countries' hospital management styles, but they are faced with similar problems with claims of patients. When a patient goes to a hospital, he/she expects good communication with doctors, nurses and officers, hopes equity and respect for his/her believing and feelings, wants service quality given in a smiling and humanity way, wishes solutions to his/her problems effectively in a short time. (Oguzhan et al., 2004). Major issues concerning proper management of hospitals are: safety and satisfaction of patients, managing finances, quality treatments, managing and retaining professionals and staff and system efficiency etc. Friesner (2009) concludes that over the years, a variety of models and schemes for hospital interventions and development have been deployed in hospitals.

Though different sectors of the society would expect hospitals to work in a non-commercial manner, the problems that a hospital faces are purely commercial. Retaining good doctors have become one of the major challenges for the hospitals and even the corporate hospitals see a rapid exodus of experienced doctors. "As they grow, the large corporate hospital networks create layers within the organization and stop being as nimble as they used to in decision making". This hampers individual autonomy and leads to the exodus of professional from one hospital to the other which is new, small and promising (The Economic Times, New Delhi, 27 September 2011 p-10). Thus changing basic practices in massive, complex healthcare organizations is especially challenging (Isern \& Pung, 2007). The performance of the hospital is conceptualized in terms of three different types of efficiency: managerial, clinical, and production efficiency and to meet that hospitals need the Continuous appraisal and adaptation to the changing needs of different components of the hospital process system. Mohr, Burgess and Young (2008) suggest that a teamwork culture in a hospital can reduce turnover thus providing cost savings and, perhaps, higher quality service to patients.

\section{Objectives of the Study}

The objectives of the study are to:

- Analyze the present human resource management policies, practices, and human relation scenario in hospitals and ascertaining whether policies are in conformity with the present day challenges and requirements of human resource.

- Make an in-depth analysis of human resource management policies, practices, and the human - relation situation prevailing in private and public hospital of the city.

\section{Hypothesis}


In the light of the above stated objectives and on the basis of a preliminary survey, the following hypothesis is framed in the present study.

"The perceptions of the Departmental Heads and Chief Executives in Public and Private Hospitals are indistinguishable with respect to diagnosing human resource management problems such as upward-downward communication, transparency of work, red-tapism etc."

\section{Research Methodology}

This study is explanatory in nature and it aims at analysing general problems in the functioning of human resource management in hospitals and variables related with it. In the present study the districts of Allahabad and Lucknow (U.P. India) have been selected for investigation. The population of the present study includes administrative and functional staff (including doctors) of the public and private hospitals based in Allahabad and Lucknow regions of Uttarpradesh

\subsection{Sample and Sample Size}

From the universe i.e. districts of Allahabad and Lucknow, a list of all the public sector (including university hospitals) and private sector hospitals was obtained. Chief executives, departmental heads and doctors at the professor level were chosen to study the hypothesis. Total effective sample size for the study was 200. This size includes 100 personnel from public hospitals and 100 personnel from private hospitals. Stratified Random Sampling Technique was used to decide the sampling composition. Composition of sample is displayed in Table 1.

Table 1: Composition of Sample

\begin{tabular}{|c|c|c|c|c|}
\hline $\begin{array}{c}\text { Type of } \\
\text { Hospital }\end{array}$ & $\begin{array}{c}\text { At the level of } \\
\text { Chief Executives }\end{array}$ & $\begin{array}{c}\text { Departmental } \\
\text { Head }\end{array}$ & Professors & Total \\
\hline Public & 10 & 30 & 60 & 100 \\
\hline Private & 16 & 36 & 48 & 100 \\
\hline
\end{tabular}

\subsection{The period of the Study}

The complete study was conducted from January 2009 to April 2012. The time span of data collection was July 2010 to May 2011.

\subsection{Instrument}

The questionnaire method was chosen as a tool to collect the required data for the reason of its being simple and getting first hand and current information. Talluru (2003) developed the questionnaire to analyze the perception of doctors, nursing staff, departmental heads and chief executives towards organizing function, staffing function and diagnosing management problems. The same questionnaires have been used with some modification catering to the needs of the local population and conditions. The Likert type statements have been used with the options for the response being- Agree, Disagree, Don't know. All items of this questionnaire are positive statements. 


\subsection{Collection of Data}

Permission was sought from the respective hospitals for conducting the study. Each participant was approached by the investigator personally, who introduced himself and explained the purpose of the study to the subjects. Each respondent was informed about the objectives and significance of the study and consent was taken before administration of the questionnaire. A questionnaire, along with a covering letter explaining the objectives of the study and the method of completing the questionnaire was given to each subject in the population. An assurance regarding confidentiality of the results was also provided. The participant was assured that his/her responses would be kept confidential and that complete anonymity would be maintained.

\subsection{Statistical Techniques Used}

The objective of this study is to observe whether the two hospitals (public and private) could be distinguished with respect to diagnosing management problems. For this purpose, an attempt has been made to compare the performance and functioning on the basis of the count of responses for 'Agree', 'Disagree', 'Don't know' type answers. Two-Sample t-test is used to evaluate the hypothesis.

\subsection{Delimitations of the Study}

- The population under study is limited to the municipal limits of the Allahabad Municipal Area (Uttar Pradesh, India).

- The sample size of the present study is limited to 200 personnel only.

- Basic limitation of the study is that, even though utmost care has been taken in selecting the sample, the results derived from a study may not be exactly equal to the true value of the population. Hence results of the study are considered to be true and relationships hold good, only for this study. Though all efforts were made to get the correct response from the respondent, biasing by the respondent may happen in some questions.

- The present study is limited in its design, method, measuring devices and statistical techniques.

\section{Data Analysis}

Questionnaire was administered to the head of the departments, chief executives and doctors at professor level of the hospitals and their perception towards HR management functions is recorded in the form of 'Agree', 'Disagree' \& 'Don't know'. These responses are then tabulated percentage wise to analyze the individual statements (Table 2). Further, t test has been applied to know if there exists any significant difference between the perception of public and private hospitals on organizing dimension. 
Table 2: Perceptions of the Departmental Heads and Chief Executives towards Hospital HR Management Issues

\begin{tabular}{|c|c|c|c|c|}
\hline S. No. & Particulars & & Public & Private \\
\hline 1. & $\begin{array}{l}\text { Heads of the Departments are behind } \\
\text { schedule in delivering the services } \\
\text { occasionally }\end{array}$ & $\begin{array}{l}\text { Agree } \\
\text { Don't know } \\
\text { Disagree } \\
\text { Total }\end{array}$ & $\begin{array}{l}83 \\
4 \\
13 \\
100\end{array}$ & $\begin{array}{l}23 \\
8 \\
69 \\
100\end{array}$ \\
\hline 2. & $\begin{array}{l}\text { Attendance to the scheduled staff meetings } \\
\text { to review the problems of implementation } \\
\text { is high }\end{array}$ & $\begin{array}{l}\text { Agree } \\
\text { Don't know } \\
\text { Disagree } \\
\text { Total }\end{array}$ & $\begin{array}{l}29 \\
8 \\
63 \\
100 \\
\end{array}$ & $\begin{array}{l}81 \\
4 \\
15 \\
100 \\
\end{array}$ \\
\hline 3. & $\begin{array}{l}\text { There is a clear idea about the tasks to be } \\
\text { performed }\end{array}$ & $\begin{array}{l}\text { Agree } \\
\text { Don't know } \\
\text { Disagree } \\
\text { Total }\end{array}$ & $\begin{array}{l}17 \\
8 \\
75 \\
100\end{array}$ & $\begin{array}{l}73 \\
15 \\
12 \\
100\end{array}$ \\
\hline 4. & $\begin{array}{l}\text { Departmental heads report to the top } \\
\text { management the things they like to hear }\end{array}$ & $\begin{array}{l}\text { Agree } \\
\text { Don't know } \\
\text { Disagree } \\
\text { Total }\end{array}$ & $\begin{array}{l}71 \\
12 \\
17 \\
100\end{array}$ & $\begin{array}{l}27 \\
12 \\
61 \\
100\end{array}$ \\
\hline 5. & $\begin{array}{l}\text { Top Management always takes time to } \\
\text { listen to the difficulties of departmental } \\
\text { activities }\end{array}$ & $\begin{array}{l}\text { Agree } \\
\text { Don't know } \\
\text { Disagree } \\
\text { Total }\end{array}$ & $\begin{array}{l}17 \\
21 \\
62 \\
100 \\
\end{array}$ & $\begin{array}{l}88 \\
4 \\
8 \\
100 \\
\end{array}$ \\
\hline 6. & $\begin{array}{l}\text { There is a shortage of funds during past one } \\
\text { year }\end{array}$ & $\begin{array}{l}\text { Agree } \\
\text { Don't know } \\
\text { Disagree } \\
\text { Total }\end{array}$ & $\begin{array}{l}92 \\
4 \\
4 \\
100\end{array}$ & $\begin{array}{l}38 \\
8 \\
54 \\
100 \\
\end{array}$ \\
\hline 7. & The agreed targets are easily met & $\begin{array}{l}\text { Agree } \\
\text { Don't know } \\
\text { Disagree } \\
\text { Total }\end{array}$ & $\begin{array}{l}4 \\
8 \\
88 \\
100 \\
\end{array}$ & $\begin{array}{l}73 \\
8 \\
19 \\
100 \\
\end{array}$ \\
\hline 8. & $\begin{array}{l}\text { Members of the department are fully } \\
\text { supportive }\end{array}$ & $\begin{array}{l}\text { Agree } \\
\text { Don't know } \\
\text { Disagree } \\
\text { Total }\end{array}$ & $\begin{array}{l}4 \\
13 \\
83 \\
100 \\
\end{array}$ & $\begin{array}{l}81 \\
4 \\
15 \\
100 \\
\end{array}$ \\
\hline
\end{tabular}




\begin{tabular}{|c|c|c|c|c|}
\hline 9. & $\begin{array}{l}\text { The payment of salaries and incentives are } \\
\text { in time }\end{array}$ & $\begin{array}{l}\text { Agree } \\
\text { Don't know } \\
\text { Disagree } \\
\text { Total }\end{array}$ & $\begin{array}{l}58 \\
13 \\
29 \\
100\end{array}$ & $\begin{array}{l}69 \\
16 \\
15 \\
100\end{array}$ \\
\hline 10. & $\begin{array}{l}\text { Heads of the department are adequately } \\
\text { trained }\end{array}$ & $\begin{array}{l}\text { Agree } \\
\text { Don't know } \\
\text { Disagree } \\
\text { Total }\end{array}$ & $\begin{array}{l}21 \\
4 \\
75 \\
100\end{array}$ & $\begin{array}{l}77 \\
12 \\
11 \\
100\end{array}$ \\
\hline 11. & $\begin{array}{l}\text { Staff members are not adequately trained } \\
\text { for what they are doing }\end{array}$ & $\begin{array}{l}\text { Agree } \\
\text { Don't know } \\
\text { Disagree } \\
\text { Total }\end{array}$ & $\begin{array}{l}67 \\
16 \\
17 \\
100 \\
\end{array}$ & $\begin{array}{l}38 \\
8 \\
54 \\
100 \\
\end{array}$ \\
\hline 12. & $\begin{array}{l}\text { The level of clarity in the staff members } \\
\text { with respect to the duties and } \\
\text { responsibilities }\end{array}$ & $\begin{array}{l}\text { Agree } \\
\text { Don't know } \\
\text { Disagree } \\
\text { Total }\end{array}$ & $\begin{array}{l}8 \\
4 \\
88 \\
100\end{array}$ & $\begin{array}{l}54 \\
12 \\
34 \\
100\end{array}$ \\
\hline 13. & $\begin{array}{l}\text { There is a shortage of supplies during past } \\
\text { one year }\end{array}$ & $\begin{array}{l}\text { Agree } \\
\text { Don't know } \\
\text { Disagree } \\
\text { Total }\end{array}$ & $\begin{array}{l}88 \\
4 \\
8 \\
100\end{array}$ & $\begin{array}{l}42 \\
8 \\
50 \\
100\end{array}$ \\
\hline 14 & $\begin{array}{l}\text { There is coordination with other } \\
\text { departments }\end{array}$ & $\begin{array}{l}\text { Agree } \\
\text { Don't know } \\
\text { Disagree } \\
\text { Total }\end{array}$ & $\begin{array}{l}8 \\
4 \\
88 \\
100 \\
\end{array}$ & $\begin{array}{l}62 \\
8 \\
30 \\
100 \\
\end{array}$ \\
\hline 15 & $\begin{array}{l}\text { Top Management is not fully informed } \\
\text { about the work }\end{array}$ & $\begin{array}{l}\text { Agree } \\
\text { Don't know } \\
\text { Disagree } \\
\text { Total }\end{array}$ & $\begin{array}{l}67 \\
8 \\
25 \\
100 \\
\end{array}$ & $\begin{array}{l}15 \\
15 \\
70 \\
100 \\
\end{array}$ \\
\hline 16 & $\begin{array}{l}\text { Job description has been reviewed and } \\
\text { updated in the last } 3 \text { years }\end{array}$ & $\begin{array}{l}\text { Agree } \\
\text { Don't know } \\
\text { Disagree } \\
\text { Total }\end{array}$ & $\begin{array}{l}4 \\
4 \\
92 \\
100 \\
\end{array}$ & $\begin{array}{l}81 \\
4 \\
15 \\
100 \\
\end{array}$ \\
\hline 17 & $\begin{array}{l}\text { Awareness of the staff about the duties and } \\
\text { responsibilities of their departmental } \\
\text { heads }\end{array}$ & $\begin{array}{l}\text { Agree } \\
\text { Don't know } \\
\text { Disagree } \\
\text { Total }\end{array}$ & $\begin{array}{l}17 \\
21 \\
62 \\
100 \\
\end{array}$ & $\begin{array}{l}81 \\
4 \\
15 \\
100 \\
\end{array}$ \\
\hline 18 & $\begin{array}{l}\text { Heads spent too much on recording and } \\
\text { reporting }\end{array}$ & $\begin{array}{l}\text { Agree } \\
\text { Don't know }\end{array}$ & $\begin{array}{l}88 \\
4\end{array}$ & $\begin{array}{l}46 \\
4\end{array}$ \\
\hline
\end{tabular}




\begin{tabular}{|l|l|l|l|l|}
\hline & & Disagree & 8 & 50 \\
& & Total & 100 & 100 \\
\hline 19 & Norms of performance are realistic & Agree & 13 & 89 \\
& & Don't know & 4 & 4 \\
& & Disagree & 83 & 7 \\
& & Total & 100 & 100 \\
\hline 20 & The objectives are never reached on time & Agree & 88 & 15 \\
& & Don't know & 4 & 12 \\
& & Disagree & 8 & 73 \\
& & Total & 100 & 100 \\
\hline
\end{tabular}

Inferences of the questionnaire are as follows:

Occasionally, heads of the departments are behind schedule in delivering the services: The analysis reveals that $83 \%$ in public hospitals and $23 \%$ in private hospitals expressed their agreement towards the statement and accept that occasionally there is a delay in delivery of the services. $13 \%$ of the respondent in public opined that they are delivering services on time. In private hospitals, 69\% disclosed that they are in line with the schedules in delivering services. From the discussion it can be said that most of the respondents in public hospitals are behind the schedule in delivering the services. Hence the authorities of the hospital have to focus attention on this area.

Attendance to the scheduled staff meetings to review the problems of implementation is high: The analysis reveals that in public hospitals out of 100 respondents $63 \%$ stated that they are not regular. Only $29 \%$ of the respondents stated that they are regular to the scheduled staff meetings. In case of private hospitals $81 \%$ stated that they are regular to the staff meetings to review the problems of current importance. From the above discussion it can be concluded that the authorities of private sector hospitals are regular in attending the scheduled staff meetings.

There is a clear idea about the tasks to be performed: The analysis reveals that out of 100 respondents in public hospitals, $75 \%$ opined that they have no clear idea regarding the tasks to be taken. $8 \%$ of the respondents showed their inability in expressing their views. In case of private hospitals, $73 \%$ expressed their satisfaction regarding clarity in undertaking tasks. Only $12 \%$ claim that there is ambiguity amongst them with respect to tasks to be accomplished, $15 \%$ of the respondents have not given their ideas. From the discussion it can be concluded that in public hospitals, a considerable number of respondents expressed their disagreement towards the statement. In this context, it is the primary responsibility of the authorities of the said hospitals to clarify the issue related to the tasks to be performed.

Departmental heads report to the top management the things they like to hear: The analysis reveals that the majority of the respondents in public hospitals (71\%) opined that they report to the top management the things they like to hear whereas only $17 \%$ expressed their disagreement towards the statement and $12 \%$ are neutral in this regard. In private hospitals $61 \%$ expressed their disagreement, while $27 \%$ stated that they report to the top Management the things they like to hear. From the discussion it may be concluded that in 
public hospitals the percentage that pertains to 'Agree' category is high which is contrary to the principles of management.

Top Management always takes time to listen to the difficulties of departmental activities: The analysis reveals that out of 100 respondents in public hospitals, 62\% claimed that their top management does not show any interest in listening to their difficulties, whereas in private hospitals $88 \%$ of the respondents opined that the top management always listens about the department activities. From the discussion it can be said that top management is not cooperating with the departmental heads in public hospitals.

There is a shortage of funds during past one year: The analysis reveals that in public hospitals out of 100 respondents $92 \%$ are in opinion that they have experienced a shortage of funds during the one year. In case of private hospitals, 54\% are comfortable with the funds. From the discussion it can be said that the majority of the respondents in public hospitals is facing problems with lack of funds.

The agreed targets are easily met: The analysis reveals that in public hospitals, $88 \%$ expressed their disagreement towards the statement. $73 \%$ of the respondents in private hospitals opined that they are easily achieving the targeted results within the stipulated period. From the discussion it can be concluded that it is becoming difficult for the staff who are working in public hospitals to meet the targets. The authorities of public hospitals have to create an environment where the employees can work with utmost motivation.

Members of the department are fully co-operative: The analysis reveals that in the case of private hospitals $81 \%$ are happy with respect to intradepartmental relations. $13 \%$ in public hospitals and $41 \%$ in private hospitals have not expressed their opinions and showed neutral attitude. $83 \%$ of the respondents in public hospitals are not happy with intradepartmental relations. From the discussion it can be said that private hospitals are enjoying maximum cooperation when compared to the public hospitals.

The payment of salaries and incentives are in time: The analysis reveals that in public hospitals out of 100 respondents, 58\% stated that they are receiving salaries and incentives in time whereas $29 \%$ claimed that they are not recognized properly by the authorities. In private hospitals out of 100 respondents, 69\% said that they are paid on time. But $15 \%$ are dissatisfied. It can be said that $13 \%$ of the respondents from public hospitals and $16 \%$ of private hospitals have shown their neutral attitude. From the discussion it can be concluded that salaries are being paid on time in both private and public hospitals.

Heads of the department are adequately trained: The analysis reveals that in public hospitals, $75 \%$ are not happy with the training facilities and only $21 \%$ expressed their happiness. Out of 100 respondents in private hospitals, $77 \%$ stated that they are adequately trained and only $11 \%$ claimed that they are yet to be trained. From the discussion it can be said that training facilities are to be improved considerably in public hospitals.

Staff members are not adequately trained for what they are doing: The analysis reveals that in public, $67 \%$ claimed that their staff members are not adequately trained for what they are doing. Only $17 \%$ expressed their satisfaction regarding training facilities that are provided 
to the staff members. In private hospitals, $54 \%$ stated that their staff members are adequately trained for what they are doing. $16 \%$ in public hospitals and $8 \%$ in private hospitals have not given their opinion. From the discussion it can be concluded that training activity is weak in public hospitals. Authorities have to take necessary steps to improve the situation.

The level of clarity in the staff members with respect to the duties and responsibilities: The analysis reveals that in public hospitals, $88 \%$ claimed that there prevails ambiguity regarding duties and responsibilities, whereas $8 \%$ stated that there is clarity in duties and responsibilities. In private hospitals 54\% are happy with the staff members and stated that there is no ambiguity about staff duties and responsibilities. It can be said that $4 \%$ of the respondents from public hospitals and $12 \%$ private hospitals have shown their neutral attitude. From the discussion it can be concluded that the authorities of public hospitals should give clarification regarding duties and responsibilities.

Perceptions of the departmental heads on shortage of supplies: The analysis reveals that the majority of the respondents in public hospitals, $(88 \%)$ are not in a position to work with satisfaction because of shortage of supplies. Only $8 \%$ of respondents stated that they are happy with the available supplies. In case of private hospitals, $50 \%$ of the respondents expressed their disagreement towards the statement. $42 \%$ claimed that they are unhappy over the shortage of supplies. $4 \%$ in public hospitals and $8 \%$ in private hospitals have not expressed their opinions. On the whole, it can be concluded that private hospital is in a better position regarding supplies.

Perceptions of the departmental heads with respect to coordination with other departments: The analysis reveals that in public hospitals, $88 \%$ of the respondents claimed that coordination with other departments is becoming difficult. Whereas in case of private hospitals out of 100 respondents, $62 \%$ stated that they are not facing any coordination problem. $4 \%$ and $8 \%$ of the respondents expressed neutral attitude in public and private hospitals respectively. From the discussion it can be concluded that most of the respondents in private hospitals are happy as far as coordination with other departments is concerned.

Top Management is not fully informed about the work: The analysis reveals that in public hospitals, it is observed that the majority of the respondents $(67 \%)$ is not informing the work progress to the top management, whereas in private hospitals a major percentage of the respondents $70 \%$ stated that they inform the work to the top management well in advance. $8 \%$ in public hospitals and $15 \%$ in private hospitals have not disclosed their opinions. From the discussion it can be concluded that the majority of the respondents in private hospitals is working in the right direction when compared to the public hospitals.

Job description has been reviewed and updated in the last 3 years: The analysis reveals that in public hospitals, $92 \%$ respondents disagreed with the statement that there is review of the job description in the last three years and $4 \%$ of respondents expressed their agreement as well as neutral attitude. In private hospitals, $81 \%$ said that their job descriptions are being updated periodically and $15 \%$ are not happy and expressed their disagreement towards the statement. From the discussion it can be concluded that as job descriptions are to be updated periodically for successful results. The authorities of public hospitals have to be cautious in 
this regard.

Staff is aware about the duties and responsibilities of their departmental heads: The analysis reveals that in public hospitals, $62 \%$ stated that their staff members do not know their head's duties and responsibilities. Whereas in private hospitals, $81 \%$ of the respondents made it clear that their staffs were aware about the head's duties and responsibilities. $21 \%$ in public hospitals and $4 \%$ in private hospitals stated they did not know about the duties and responsibilities of heads. From the discussion it may be concluded that as human relations are important for managerial success, the authorities of public hospitals have to focus in this regard.

Heads spent too much on recording and reporting: The analysis reveals that most of the respondents in public hospitals $(88 \%)$ complained that they are spending much time on recording and reporting. Whereas in private hospitals, $50 \%$ of the respondents are happy with the present system and $46 \%$ opined that the existing system should be further simplified. $4 \%$ of private hospitals and $4 \%$ in public hospitals have not given their opinion. From the analysis it can be concluded that most of the respondents in public hospitals and a reasonably good number of respondents in private hospitals are not happy with the present system of recording.

Norms of performance are realistic: The analysis reveals that the majority of the respondents in public hospitals $83 \%$ opined that that their performance norms are not realistic. In private hospitals out of 100 respondents, $89 \%$ opined that their norms of performance are accurate. $4 \%$ in public hospitals and $4 \%$ in private hospitals expressed their neutral attitude. From the discussion it can be said that most of the respondents in private hospitals are happy with respect to norms of performance.

The objectives are never reached on time: The analysis reveals that in public hospitals out of 100 respondents, $88 \%$ expressed their agreement to the statement. In private hospitals, $73 \%$ said that they reached objectives within stipulated period. $4 \%$ in public hospitals and $12 \%$ in private hospitals expressed their neutral attitude towards the statement. From the analysis it can be concluded that the majority of the respondents in public hospitals said that they never reached their objective on time.

\subsection{Hypothesis Evaluation}

To test the significance of the difference in the thinking of the personnel of the two types of hospitals, the 'Agree' and responses are counted and then the $t$ test is applied.

Table 3: Mean and t-Values of Chief Executives and Departmental Heads towards Hospital HR Management Issues (On the Factor: Agree)

\begin{tabular}{|l|l|l|l|}
\hline Agree & Mean 'M' & Variance & t-Value \\
\hline Public & 44.45 & 1184.261 & -1.39089 \\
\hline
\end{tabular}




\begin{tabular}{|l|l|l|l|}
\hline \hline Private & 57.7 & 630.7474 & \\
\hline
\end{tabular}

t critical two tail: 1.97 (at 0.05 significant levels)

The t-value is less than the table value at 5\% significant level (Table 3). There is no significant difference between public and private hospitals for "Agree" response. Thus the thinking of departmental heads and chief executives do not vary widely in private and public hospitals regarding diagnosing management problems.

If we compare the mean score for the "Agree" response of the department heads and chief executives belonging to public and private sector hospitals, we find that private sector departmental heads and chief executives are more satisfied with their hospital management policies. So on the management function, private hospitals are most preferred hospitals. Private hospitals follow proper management function.

\section{Conclusions}

Though public hospitals have better manpower and operational equipments yet, they lack implementing proper human resource management. Control and measurement of public hospitals are such that in spite of having lots of facilities, the private hospitals are giving tough competition to them. Private hospital is having a clear idea about their task to be performed, whereas in public hospital there is no clear idea about their tasks. It has been observed that in private hospital attendance to schedule staff meetings is high and the heads are prompt in delivering the services. Top management is active in listening to the problems of departmental heads. There is no shortage of funds and they are meeting their targets easily. Salaries and incentives are paid regularly. There is no shortage of supplies. Coordination within departments is easy. Heads are spending reasonable time for recording and reporting. The performances are realistic and objectives are reached within time.

The funds of public hospitals are not utilized properly for the purpose for which it has been sanctioned whereas in private hospital they utilize every single rupee of the fund. There is absence of ownership and accountability in public hospitals, as the control is in the hand of government. Whereas the control of the private hospital are in hand of one person and due to which decisions don't get delayed and the funds are spent in the same ratio in which they are sanctioned.

Public hospitals are mostly interested in the need base training, whereas private hospitals focus for increasing efficiency of the staff with the proper training schedule. Human relations aspect among staff members and top management of public hospital are not as good as being in private hospitals. Staff members of a private hospital work like family as they all contribute in the management decision making process and suggestions from every staff is implemented, if that suggestion is best for the hospital.

Thus it can be concluded that, in-spite of various recommendations and suggestions offered by various researchers and other bodies on the issue of improvements in organizational design of hospitals, this research yet again the highlights inability of the public hospitals to 
adopt the new concepts of human resource management.

\section{Acknowledgement}

The paper is a part of the $\mathrm{Ph}$. D work submitted to Uttar Pradesh Rajershree Tandon Open University. Authors of this paper are really grateful to the work of and questionnaire constructed by Talluru (2003) which gave us an idea to explore the functioning of public and private sector hospitals in different regional and demographic settings.

\section{References}

Baru, R. V., Qadeer, I., \& Priya, R. (2000). Medical industry: Illusion of quality at what cost? Economic and Political Weekly Vol. 35, No. 28/29 (Jul. 15-21, 2000), pp. 2509-2511.

Friesner, D., Neufelder, D., Raisor, J., \& Bozman, C.S. (2009). How to improve patient satisfaction when patients are already satisfied: A continuous process- Improvement Approach. Hospital Topics, Winter 2009, 87, 1, pp. 24-40.

Heine, P. R. \& Maddox, N. E (2007) Hospital management reform: a step to healthcare reform. Journal of Management and Marketing Research pp. 1-7.

Isern, J., \& Pung, C. (2007). Driving radical change. The McKinsey Quarterly, 4, 24, 2007.

Mohr, D.C., Burgess, J.F. \& Young, G.J. (2008). The influence of teamwork culture on physician and nurse resignation rates in hospitals. Health Services Management Research, 2 (1), pp. 23-31.

Oguzhan, T., Bebitglu, G., \& Ustu, Y. (2004). Hospital administration operations in Turkey. Journal of the Academy of Hospital Administration, 16(2).

PricewaterhouseCoopers. (2007). Healthcare in India, Emerging market report.

Scott, W. R. (1966). Some implications of organization theory for research on health services, Milbank Memorial Fund Quarterly 44:35-64.

Talluru, S. (2003). Management of Hospitals, New Delhi, APH Publishing Corporation The Economic Times, New Delhi, 27 September 2011 p. 10. 